\title{
On a remarkable phenomenon of oxidation of pure aluminium when in contact with mercury
}

\section{E. O. Erdmann}

To cite this article: E. O. Erdmann (1893) On a remarkable phenomenon of oxidation of pure aluminium when in contact with mercury, Philosophical Magazine Series 5, 36:218, 151-151, DOI: $10.1080 / 14786449308620460$

To link to this article: http://dx.doi.org/10.1080/14786449308620460

曲 Published online: 08 May 2009.

Submit your article to this journal $[\pi$

Џ Article views: 2

Q View related articles $\square$ 
cancelled. In Table XXI., Section 6 , the ratio $k / \beta$ for $\mathrm{CO}_{2}$ is given as 4 instead of $2 \cdot 5$, the logarithm baving been copied in place of the number.

Melbourne, April 1893.

Yours obediently, William Sutherdand.

ON A REMARKABLE PHENOMENON OF OXIDATION OF PURE ALUMINICM WHEN IN CONTACT WITH MERCURY. BY E. 0 . ERDMANN.

As soon as the two metals are in actual contact, snow-white filiform or straw-shaped formations result, growing from the point of contact of the two metals, which in a few minutes acquire a length of 2 to 3 centim. Under the microscope they appear as tube-shaped or plate-shaped veils, of extreme delicacy and perfectly amorphous. If they are detached by tapping or shaking they look like lint. Chemical investigation shows that they consist of pure aluminium hydrate.

It is immaterial for the formation of this oxide whether the contact between the metals is effected by rubbing, or whether the surfaces are purified with hydrochloric acid or caustic soda, and subsequent washing with much water and drying with blottingpaper.

The cause of this peculiar oxidation might be sought for in :-

(1) The formation of an easily oxidizable amalgam of aluminium, which always forms at the surface of contact in the degree in which aluminium oxidizes in moist air.

(2) The electrolytic decomposition of a thin layer of water, which is condensed on the surfaces of the two metals which form the element.

(3) That the highly positive aluminium by contact with mercury acquires a greater affinity for oxygen, in the same manner as, according to Magnus, iron-filings do when hanging to a magnet.Physical Society of Berlin, November 18, 1892 ; from Wiedemann's Annalen, No. 1, 1893.

ON THE PROCESSES WHICH TAKE PLACE AT THE BOUNDARY BETWEEN TWO SOLUTIONS OF DIFEHRENT CONCENTRATION WHEN A CURRENT IS PASSED, BY GEORGE H. ZAHN.

The results of these experiments are stated by the author as follows. Besides the well-known formation of hydroxides of magnesium, calcium, and copper above the boundary of a dilute solution over a concentrated one of the same salt when an electrical current passes from the concentrated to the dilute solution, it is possible, when the concentrations are very different, to observe the formation of a solid with barium, strontium, alumininm, iron, manganese, and zinc in combination with several acids. Silver does not exhibit such a behaviour. In each case, even with silver, and with the salts of potassium and of sodium, which form readily 